\title{
Death Diagnosis Data Collection Date Time
}

National Cancer Institute

\section{Source}

National Cancer Institute. Death Diagnosis Data Collection Date Time. NCI Thesaurus.

Code C117549.

The date and time of death diagnosis data collection. 